\title{
Intravenous or inhaled salbutamol in severe acute asthma?
}

\author{
STEPHEN WILLIAMS AND ANTHONY SEATON
}

From the Asthma Research Unit, Sully Hospital, Penarth, South Glamorgan CF6 2 Y A, UK

\begin{abstract}
Williams, S., and Seaton, A. (1977). Thorax, 32, 555-558. Intravenous or inhaled salbutamol in severe acute asthma? Ten patients with life-threatening attacks of asthma ('status asthmaticus') were treated with salbutamol inhaled by intermittent positive pressure breathing, and their response in terms of rise in peak flow rate was measured. They were then given intravenous salbutamol and any further increment in peak flow was measured. Hydrocortisone treatment was started simultaneously and the responses to salbutamol were re-measured on each of the next three days. Only two patients initially responded to the aerosol, whereas all save one responded to the intravenous drug. The two who responded initially to the aerosol were the two who were able to produce sputum at the time of admission. All patients subsequently responded to the aerosol, and the onset of this response correlated closely with the beginning of sputum production. Sympathomimetics should be given parenterally to patients in severe asthma if the response to inhaled drug is reduced or absent.
\end{abstract}

Corticosteroids may take several hours or even days before producing a measurable improvement in ventilatory function in patients with severe asthma (Collins et al., 1975).

Bronchodilators are usually necessary during this period and $\beta$-stimulant drugs are commonly used though it has been reported that the $\beta$ effects of adrenergic stimulation are of ten diminished in severe asthma (Cookson and Read, 1963; EllulMicallef and Fenech, 1975). The $\beta-2$ stimulant drug, salbutamol, when given by intermittent positive pressure nebulisation (IPPB), has been shown to produce significant bronchodilatation in chronic asthmatics (Choo-Kang et al., 1970) while it is also effective given intravenously in severe acute asthma (Fitchett et al., 1975; Williams et al., 1975). The purposes of the present study were to determine the best mode of administration of salbutamol at various times during a severe asthmatic attack and to investigate the possibility of $\beta$ receptor blockade in these patients.

\section{Methods}

The study protocol was approved by the area ethics committee. Ten patients gave informed consent. All were admitted with severe asthma satisfying the criteria of a pulse $>120$ per minute, peak flow rate $<25 \%$ predicted, and a $\mathrm{PaO}_{2}<70 \mathrm{mmHg}$
$(9 \cdot 3 \mathrm{kPa})$. Eight had been using sympathomimetic inhalers before the attack (Table 1). None had any therapy in the two hours before entry to the trial.

The peak flow rate (PFR-best of three attempts) was measured on admission by Wright peak flow meter. An aerosol of $5 \mathrm{mg}$ salbutamol was then given by positive pressure nebulisation (Ohio hand-e-vent) supervised in all cases by one of us (SW). PFR was then measured at 5-minute intervals until a maximum was reached. At this time salbutamol $(200 \mu \mathrm{g})$ was injected intravenously over 10 minutes. PFR continued to be recorded every 5 minutes until a plateau occurred. The whole procedure was repeated at 24-hour intervals for three days.

Each patient was also treated with intravenous hydrocortisone (1 g 6-hourly initially), oral prednisone, oxygen, and antibiotics, these being started at the time of admission. Each patient was asked at the time of the daily salbutamol tests whether he had produced any sputum in the preceding 24 hours. The first 24 -hour period in which he did this was recorded (eg, on admission or on days 1,2 or 3 ) (Table 1 ).

\section{Results}

Analysis of results was by Student's $t$ test for 
Table 1 Clinical details of patients studied

\begin{tabular}{|c|c|c|c|c|c|c|}
\hline Case & $\operatorname{Sex}$ & Age $(y r)$ & $\begin{array}{l}\text { Duration of } \\
\text { previous } \\
\text { asthma }(y r)\end{array}$ & $\begin{array}{l}\text { Duration of } \\
\text { episode } \\
\text { studied }\end{array}$ & $\begin{array}{l}\text { Maintenance } \\
\text { therapy }\end{array}$ & $\begin{array}{l}\text { Day of sputum } \\
\text { production }\end{array}$ \\
\hline 1 & $\mathbf{M}$ & 41 & 25 & 3 weeks & $\begin{array}{l}\text { Prednisone } \\
\text { Salbutamol inhaler }\end{array}$ & On admission \\
\hline 2 & $\mathbf{F}$ & 22 & 12 & 2 days & $\begin{array}{l}\text { Prednisone } \\
\text { Medihaler }\end{array}$ & 1 \\
\hline 3 & $\mathbf{M}$ & 22 & 10 & 2 days & None & 1 \\
\hline 4 & $\mathbf{M}$ & 37 & 20 & 14 hours & $\begin{array}{l}\text { Prednisone } \\
\text { Medihaler }\end{array}$ & 1 \\
\hline 5 & $\mathbf{F}$ & 19 & 10 & 2 weeks & $\begin{array}{l}\text { Prednisone } \\
\text { Salbutamol inhaler }\end{array}$ & 3 \\
\hline 6 & $\mathbf{M}$ & 53 & 2 & 1 week & Salbutamol inhaler & 2 \\
\hline 7 & $\mathbf{F}$ & 51 & 10 & 5 days & $\begin{array}{l}\text { Prednisone } \\
\text { Salbutamol inhaler }\end{array}$ & 3 \\
\hline 8 & $\mathbf{F}$ & 49 & 10 & 3 days & Salbutamol inhaler & On admission \\
\hline 9 & $\mathbf{M}$ & 54 & 25 & 1 week & $\begin{array}{l}\text { Prednisone } \\
\text { Brovon inhaler }\end{array}$ & 1 \\
\hline 10 & $\mathbf{M}$ & 54 & 0 & 2 days & None & 1 \\
\hline
\end{tabular}

Table 2 Peak flow rate (PFR) before drug administration and rise after inhaled and intravenous salbutamol: means, standard deviation in parentheses

\begin{tabular}{|c|c|c|c|c|c|c|c|c|c|c|c|}
\hline & \multirow{2}{*}{$\begin{array}{l}\text { Initial } \\
\text { PFR } \\
(\text { l/min })\end{array}$} & \multicolumn{5}{|c|}{$\begin{array}{l}\text { Differences between initial PFR and PFR after } \\
\text { inhaled salbutamol }(1 / \mathrm{min})\end{array}$} & \multicolumn{5}{|c|}{$\begin{array}{l}\text { Differences between initial PFR and PFR after } \\
\text { intravenous salbutamol (l/min) }\end{array}$} \\
\hline & & 0 & $5 \min$ & $10 \mathrm{~min}$ & $15 \mathrm{~min}$ & $20 \mathrm{~min}$ & 0 & $5 \mathrm{~min}$ & $10 \mathrm{~min}$ & $15 \mathrm{~min}$ & $20 \mathrm{~min}$ \\
\hline On admission & $\begin{array}{l}91 \\
(27)\end{array}$ & $\begin{array}{l}8 \cdot 5 \\
(17)\end{array}$ & $\begin{array}{l}7 \cdot 5 \\
(14)\end{array}$ & $\begin{array}{l}2 \cdot 5 \\
(12)\end{array}$ & $\begin{array}{c}3 \\
(13)\end{array}$ & $\begin{array}{l}0 \cdot 5 \\
(11)\end{array}$ & $\begin{array}{c}25 \\
(21)\end{array}$ & $\begin{array}{c}35 \\
(26)\end{array}$ & $\begin{array}{c}40 \\
(25)\end{array}$ & $\begin{array}{c}49 \\
(23)\end{array}$ & $\begin{array}{c}54 \\
(27)\end{array}$ \\
\hline Day 1 & 140 & $\begin{array}{l}35 \\
(27)\end{array}$ & $\begin{array}{l}42 \\
(24)\end{array}$ & $\begin{array}{l}45 \\
(17)\end{array}$ & $\begin{array}{c}40 \\
(16)\end{array}$ & $\begin{array}{l}39 \\
(19)\end{array}$ & $\begin{array}{l}56 \\
(21)\end{array}$ & 59 & $\begin{array}{c}68 \\
(22)\end{array}$ & $\begin{array}{c}67 \\
(21)\end{array}$ & $\begin{array}{c}67 \\
(18)\end{array}$ \\
\hline Day 2 & $\begin{array}{l}176 \\
(14)\end{array}$ & $\begin{array}{c}31 \\
(16)\end{array}$ & $\begin{array}{c}38 \\
(14)\end{array}$ & $\begin{array}{c}43 \\
(13)\end{array}$ & $\begin{array}{c}46 \\
(15)\end{array}$ & $\begin{array}{c}47 \\
(16)\end{array}$ & $\begin{array}{c}65 \\
(23)\end{array}$ & $\begin{array}{c}63 \\
(23)\end{array}$ & $\begin{array}{c}66 \\
(30)\end{array}$ & $\begin{array}{c}69 \\
(22)\end{array}$ & $\begin{array}{c}70 \\
(21)\end{array}$ \\
\hline Day 3 & $\begin{array}{l}195 \\
(77)\end{array}$ & $\begin{array}{c}46 \\
(20)\end{array}$ & $\begin{array}{c}51 \\
(24)\end{array}$ & $\begin{array}{c}62 \\
(23)\end{array}$ & $\begin{array}{c}68 \\
(26)\end{array}$ & $\begin{array}{c}64 \\
(26)\end{array}$ & $\begin{array}{c}69 \\
(17)\end{array}$ & $\begin{array}{c}73 \\
(31)\end{array}$ & $\begin{array}{c}73 \\
(35)\end{array}$ & $\begin{array}{c}78 \\
(34)\end{array}$ & $\begin{array}{c}73 \\
\text { (33) }\end{array}$ \\
\hline
\end{tabular}

paired samples. Table 2 shows that the mean initial PFR on the day of admission was $91 \mathrm{l} / \mathrm{min}$ and after inhalation of salbutamol there was no significant increase. In individual patients only two of the 10 showed a rise of greater than $10 \%$ in PFR after the inhalation. These two patients were the only ones who were producing sputum at the time of admission.

After the intravenous salbutamol, the mean PFR of the 10 patients showed a significant rise to $145 \mathrm{l} / \mathrm{min}$. Only one of the 10 patients failed to show a rise after intravenous salbutamol and those two who had responded to aerosol also showed an additional response to the intravenous drug. This rise after intravenous drug was statistically significant $(P<0.01)$.

Each day there was an increase in the initial mean PFR of the patients in keeping with their expected responses to high-dose steroids. Along with this initial rise there was an increased response to inhaled salbutamol and a progressively smaller increment after intravenous salbutamol. On day three there was a maximal response to the aerosol and no significant further increase after the intravenous drug (Table 2). This pattern of response occurred in all 10 patients.

The response to aerosol salbutamol related closely to sputum production. The two who re응 sponded initially were the only ones who were prox ducing sputum. Table 3 shows the mean PFR before and on the day of sputum production in the other eight patients. There was a significane response to intravenous salbutamol before sputum production and to aerosol after sputum produc음 tion. The baseline PFR, before drug admin 7 istration, also increased at the time of sputume. production, as seen in Table 3.

The pattern of response did not relate to previous duration of asthma, duration of the attack or administration of oral steroids before admis $\omega$ sion. Increased skill in the use of the IPPB device did not seem to play a part as its use was supere vised by one of us in all patients and there was nod difference in response between those who had? previously used the device and those who had not

\section{Discussion}

We have shown that severe asthma may prove fatal in a very short space of time (Macdonald 
Table 3 Mean peak flow rate (PFR) and SD after inhaled and intravenous salbutamol on the day before and the day of sputum production in the eight patients not producing sputum on admission

\begin{tabular}{lll}
\hline & $\begin{array}{l}\text { Day before } \\
\text { sputum } \\
\text { production }\end{array}$ & $\begin{array}{l}\text { Day of } \\
\text { sputum } \\
\text { production }\end{array}$ \\
\hline $\begin{array}{l}\text { Initial PFR (1/min) } \\
\text { P (initial } v \text { max after inhalation) } \\
\text { Maximum PFR after inhaled }\end{array}$ & $\begin{array}{l}94(24) \\
\quad \text { salbutamol }\end{array}$ & $\begin{array}{l}149(37) \\
<0.05\end{array}$ \\
$\begin{array}{l}\text { P (max after inhaled } v \text { max after IV) } \\
\text { Maximum PFR after intravenous } \\
\text { salbutamol }\end{array}$ & $\begin{array}{l}107(28) \\
<0.05\end{array}$ & $\begin{array}{l}205(49) \\
>0.05\end{array}$ \\
\hline
\end{tabular}

et al., 1976a; Macdonald et al., 1976b). It is important, therefore, that the initial treatment should be the most effective available. Hume and Gandevia (1957) were probably the first to demonstrate that the response to inhaled bronchodilators in asthma varied in an individual in relation to the severity of his airways obstruction. In their subjects, severe obstruction was associated with little response. There was then an increasing response as the obstruction was relieved and subsequently a smaller response again as the subject's maximal state of bronchodilatation was achieved. Other workers, notably Rebuck and Read (1971), have confirmed that in severe attacks of asthma the patients are frequently in a non-responsive phase, and the latter authors used this as an index of severity of the attack.

The reasons for this failure to respond to inhaled bronchodilators have not hitherto been clarified. In severe asthma, not only is bronchial smooth muscle constriction present, but also mucosal thickening, bronchial wall oedema, and mucus plugging play a major part in causing airways obstruction (Williams and Leopold, 1959). This mechanism of bronchial narrowing would not be expected to respond to bronchodilators and moreover might be expected to prevent the access of inhaled drugs.

In addition it has been suggested that severe asthmatics may develop partial $\beta$-receptor blockade (Cookson and Reed, 1963) and that this potentially dangerous effect may be relieved by corticosteroids (Rebuck and Reed, 1971; Shenfield et al., 1975). Studies of this effect have generally relied upon failure of $\beta$-stimulant drugs given by aerosol to produce bronchodilatation.

In a previous study (Williams et al., 1975), we have shown that intravenous salbutamol is effective in severe acute asthma. We have now shown that inhaled salbutamol, like isoprenaline, is not normally effective in the same clinical situation until the patient begins to cough up the mucus that has been plugging the bronchi. That this lack of efficacy is not due to $\beta$-blockade has been demonstrated by the significant effect of intravenous salbutamol at a time when the aerosol produces no response. Only one of our patients failed initially to respond to both aerosol and intravenous salbutamol. In his case $\beta$-blockade is a possibility, but an alternative and equally likely reason is that his airways were predominantly obstructed by mucus plugging and that smooth muscle constriction was initially playing only a minor role. This patient had used no bronchodilators before his admission in this attack. Clearly, the possibility of $\beta$-blockade as an important factor in severe asthma is hard to prove, but from our studies it is plain that it cannot be assumed from a failure to respond to bronchodilators given by aerosol alone. Moreover, socalled potentiation of bronchodilators by steroids (Shenfield et al., 1975) may be explained on the basis of improving access of the bronchodilators to the airways as well as by biochemical mechanisms. In our patients there was, as expected, a rise in the baseline peak flow each day and this was undoubtedly the effect of corticosteroid treatment. Nevertheless, we were able to achieve a rise in peak flow from 91 to $1451 / \mathrm{min}$ after intravenous salbutamol on the first day-a percentage change comparing favourably with that from 195 to $259 \mathrm{l} / \mathrm{min}$ after inhaled salbutamol after 36 hours' high-dose corticosteroids. It seems likely that the effect of the steroids in these patients was largely to improve the accessibility of the bronchi to the inhaled drug by reducing the inflammatory reaction within them.

The practical message of our study is that the management of severe acute asthma requires administration of bronchodilators by the most effective route while waiting for corticosteroids to work. While sympathomimetics by IPPB may be effective in a number of patients, in those as severely ill as the ones we studied intravenous administration is the route of choice. When the patient begins to respond to the steroid therapy and, in particular, when he starts to produce sputum, IPPB becomes as effective as intravenous therapy.

\section{References}

Choo-Kang, Y. F. J., Parker, S. S., and Grant, I. W. B. (1970). Response of asthmatics to isoprenaline and salbutamol aerosols administered by intermittent positive-pressure ventilation. British Medical Journal, 4, 465-468. 
Collins, J. V., Clark, T. J. H., Brown, D., and Townsend, J. (1975). The use of corticosteroids in the treatment of acute asthma. Quarterly Journal of Medicine, 44, 259-273.

Cookson, D. U., and Reed, C. E. (1963). A comparison of the effects of isoproterenol in the normal and asthmatic subject. American Review of Respiratory Disease, 88, 636-643.

Ellul-Micallef, R., and Fenech, F. F. (1975). Effect of intravenous prednisolone in asthmatics with diminished adrenergic responsiveness. Lancet, 2, 1269-1271.

Fitchett, D. H., McNicol, M. W., and Riordan, J. F. (1975). Intravenous salbutamol in management of status asthmaticus. British Medical Journal, 1, 5355.

Hume, K. M., and Gandevia, B. (1957). Forced expiratory volume before and after isoprenaline. Thorax, 12, 276-278.

Macdonald, J. B., Macdonald, E. T., Seaton, A., and Williams, D. A. (1976b). Asthma deaths in Cardiff 1963-74: 53 deaths in hospital. British Medical Journal, 2, 721-723.
Macdonald, J. B., Seaton, A., and Williams, D. A. (1976a). Asthma deaths in Cardiff 1963-74: 90 deaths outside hospital. British Medical Journal, 1, 1493-1495.

Rebuck, A. S., and Read, J. (1971). Assessment and management of severe asthma. American Journal of Medicine, 51, 788-798.

Shenfield, G. M., Hodson, M. E., Clarke, S. W., and Paterson, S. W. (1975). Interaction of corticosteroids and catecholamines in the treatment of asthma. Thorax, 30, 430-435.

Williams, D. A., and Leopold, J. G. (1959). Death from bronchial asthma. Acta Allergologica, 14, 83-86.

Williams, S. J., Parrish, R. W., and Seaton, A. G (1975). Comparison of intravenous aminophylline of and salbutamol in severe asthma. British Medical or Journal, 4, 685.

Requests for reprints to: Dr. A. Seaton, Sully Hospital, Penarth, South Glamorgan CF6 2YA, UK. 